\title{
Predominant Mechanisms in the Treatment of Wastewater Due to Interaction of Benzaldehyde and Iron Slag Byproduct
}

\author{
Ayad A. H. Faisal ${ }^{1, *(\mathbb{D})}$, Saif S. Alquzweeni ${ }^{2}$, Laith A. Naji ${ }^{1}$ (i) and Mu Naushad ${ }^{3, *(1)}$ \\ 1 Department of Environmental Engineering, College of Engineering, University of Baghdad, Baghdad-10011, \\ Iraq; add.ali.lith@gmail.com \\ 2 Department of Civil Engineering, College of Engineering, University of Babylon, Babylon-51001, Iraq; \\ saifalquzweeni@gmail.com \\ 3 Department of Chemistry, College of Science, Bld\#5, King Saud University, Riyadh-11451, Saudi Arabia \\ * Correspondence: ayadabedalhamzafaisal@yahoo.com (A.A.H.F.); mnaushad@ksu.edu.sa (M.N.)
}

Received: 16 November 2019; Accepted: 26 December 2019; Published: 28 December 2019

\begin{abstract}
Iron slag is a byproduct generated in huge quantities from recycled remnants of iron and steel factories; therefore, the possibility of using this waste in the removal of benzaldehyde from contaminated water offers an excellent topic in sustainability field. Results reveal that the removal efficiency was equal to $85 \%$ for the interaction of slag and water contaminated with benzaldehyde at the best operational conditions of $0.3 \mathrm{~g} / 100 \mathrm{~mL}, 6,180 \mathrm{~min}$, and $250 \mathrm{rpm}$ for the sorbent dosage, initial $\mathrm{pH}$, agitation time, and speed, respectively with $300 \mathrm{mg} / \mathrm{L}$ initial concentration. The maximum uptake capacity of iron slag was $118.25 \mathrm{mg} / \mathrm{g}$ which was calculated by the Langmuir model. Physical sorption may be the major mechanism for the removal of benzaldehyde onto iron slag based on the analysis of isotherm and kinetic sorption data and thermodynamically, the process was spontaneous and endothermic. Finally, the X-ray fluorescence spectroscopy (XRF), X-ray diffraction (XRD), Fourier transform infrared (FT-IR), scanning electron microscope (SEM) and energy-dispersive spectroscope (EDS) tests for reactive material certified that the dissolution of calcium oxide can enhance the removal of benzaldehyde by the formation of bridge cations.
\end{abstract}

Keywords: benzaldehyde; iron slag; adsorption mechanism; cation bridge

\section{Introduction}

Benzaldehyde is one of the most industrially useful members of the aromatic aldehydes family. It may exist in combined form such as apricot, glycoside in almond, peach seeds and cherry as well as being utilized in the beverage, food, pharmaceutical, perfume, dyestuff, and soap industries. The most important use of benzaldehyde is the manufacturing of different organic products. Benzaldehyde may be released to the ecosystem with emissions of combustion processes such as incinerators, gasoline and diesel engines, and burning of wood. Photochemical oxidation of aromatic hydrocarbons like toluene can be enhanced in the formation of benzaldehyde in the atmosphere. Benzaldehyde can occur naturally in different plants and light has influenced its composition; so, benzoic acid can be produced from oxidizing benzaldehyde in air. Thus, the destruction or removal of benzaldehyde, benzoic acid and other organic compounds related to benzaldehyde from waste streams becomes a major environmental problem [1-3].

Many techniques have been developed for the removal of such types of pollutants from wastewater such as advanced oxidation processes [4], aerobic degradation [5], nano-filtration [6], ozonation [7] and others. The familiar technique is the adsorption process which has become one of the most 
effective means for transferring the solute from the liquid phase to the solid phase of a sorbent [8-13]. Adsorption can be achieved by using different material especially the activated carbon which is a very useful and effective technique in the remediation of wastewater contaminated with organic compounds [14-17]. In this regard, the previous literature was directed towards the adsorption of benzaldehyde using traditional sorbents such as activated carbon cloth [18], granular activated carbon [3], natural clay and Faujasite-Y type zeolite [19]. However, the high cost of the activated carbon and other conventional sorbents were the main constraint that limited their usage; consequently, finding non-conventional low-cost materials with good ability in the reduction of the contamination opens new horizons for many studies. In this direction, byproducts resulted from different industries such as fly ash, bottom ash, and iron slag can be tested to find their suitability for the removal of organic compounds described previously.

The granular iron slag is considered a byproduct solid wastes produced from recycled remnants of iron and steel factories. The previous studies proved that the world production of iron slag is almost $50 \times 10^{6}$ tons per year $[20,21]$. These large quantities can be accumulated on large areas of land and render it unfit for agriculture purposes. The main constituent of iron slag waste is ash from coke used as a reducing material, silica and other non-ferrous components of iron ore, and limestone auxiliary material. Accordingly, reusing this solid waste in the remediation of wastewater is considered a real application of the sustainability principles. Hence, the primary aim of this study is finding the ability of iron slag byproduct for reclamation of wastewater contaminated with benzaldehyde and specifying the predominant mechanisms of the uptake process.

\section{Materials and Methods}

\subsection{Sorbent and Contaminant}

Granular iron slag byproduct was chosen as reactive material and collected from a steel and iron factory in Talee'a city in Babil Governorate, Iraq. To remove the fine powder, distilled water was used to wash off the iron slag; then, it was dried at $383 \mathrm{~K}$ for $24 \mathrm{hrs}$. Thereafter, it was crushed and particle sizes ranging from 0.6 to $1 \mathrm{~mm}$ could be selected for achieving the experiments. The slag was kept in desiccators; however, the following tests were conducted according to the standard methods [13] for characterizing its properties and composition; (i) physical tests (porosity, surface area, and bulk density, and (ii) chemical tests ( $\mathrm{pH}$, ash content, X-ray diffraction (XRD), Fourier transform infrared (FT-IR) spectroscopy, scanning electron microscopy (SEM), energy-dispersive spectroscopy (EDS), and $\mathrm{X}$-ray fluorescence (XRF) spectroscopy).

Benzaldehyde $\left(\mathrm{C}_{7} \mathrm{H}_{6} \mathrm{O}\right)$ compound was selected to represent the organic contaminant which has the purity greater than $99 \%$. To prepare the aqueous solution contaminated with certain concentrations of benzaldehyde at room temperature, this compound was dissolved firstly in ethanol $\left(\mathrm{C}_{2} \mathrm{H}_{6} \mathrm{O}\right)$ and the mixture added to distilled water. The concentration was measured by using gas chromatograph (GC, 1000, Italia). The $0.1 \mathrm{M}$ of sodium hydroxide or nitric acid was used to reach the required value of the $\mathrm{pH}$ for the aqueous solution and measurement of this parameter was achieved by $\mathrm{pH}$-meter (WTW, Bench model, German).

\subsection{Batch Experiments}

Certain volumes of $\mathrm{C}_{7} \mathrm{H}_{6} \mathrm{O}$ aqueous solution $(100 \mathrm{~mL})$ with initial concentration $\left(C_{o}\right)$ of $300 \mathrm{mg} / \mathrm{L}$ were distributed on the series of $250 \mathrm{~mL}$ conical-flasks and $0.3 \mathrm{~g}$ of granular iron slag added to each flask. Then, the flasks have been mounted on the high-speed orbital shaker type (Edmund Buhler SM25, German) which operated at shaking speed equal to $250 \mathrm{rpm}$ for $4 \mathrm{~h}$. From each flask, $20 \mathrm{~mL}$ of the solution was filtered using a micro filter (Sartorius Stedim $0.2 \mu \mathrm{m}$ ) to separate the solid particles. The residual benzaldehyde $\left(C_{e}\right)$ was measured by gas chromatograph $(\mathrm{GC})$. The batch experiments were conducted with different operational conditions; specifically, initial $\mathrm{pH}$ of $(3,4,5,6$ and 7), initial concentration of $(300,400,500,600$ and $700 \mathrm{mg} / \mathrm{L})$, sorbent dosage of $(0.1,0.3,0.5,0.7,1.0 \mathrm{~g} / 100 \mathrm{~mL})$ 
and agitation speed of $(0,50,100,150,200$ and $250 \mathrm{rpm})$. Also, the effects of temperature variation on the sorption performance were investigated at 20,30 and $40{ }^{\circ} \mathrm{C}$. The quantity of benzaldehyde sorbed onto the sorbent $\left(q_{e}\right)$ was calculated by the following Equation [22]:

$$
q_{e}=\left(C_{o}-C_{e}\right) \frac{V}{m}
$$

where $V$ is the aqueous solution volume added to the flask (L), and $m$ is the quantity of granular iron slag in the flask $(\mathrm{g})$. The efficiency of adsorption $\left(E_{a d}\right)$ was calculated in each experiment by:

$$
E_{a d}=\frac{\left(C_{o}-C_{e}\right)}{C_{o}} \times 100
$$

\subsection{Kinetic Studies}

The kinetic data measured in the batch experimental tests were analyzed by a set of kinetic models mentioned in items from 1 to 3 [23,24]:

Pseudo-first-order model: this is utilized for description the adsorption of solid/solution system with the following exponential form:

$$
q_{t}=q_{e}\left[1-\exp \left(-k_{1} t\right)\right]
$$

where $k_{1}$ is the rate constant of the first model ( $\left.1 / \mathrm{min}\right), q_{e}$ and $q_{t}$ are the quantity of contaminant sorbed per unit mass of sorbent $(\mathrm{mg} / \mathrm{g})$ at equilibrium and time $t$ respectively.

Pseudo-second order model: it is assumed that (i) the single layer of solute must be sorbed on the solid particle, (ii) the energy of adsorption is not depended on the surface coverage, and (iii) sorbed species must not interact. The expression of the second model has the following non-linear formula:

$$
q_{t}=\frac{k_{2} q_{e}^{2} t}{\left(1+k_{2} q_{e} t\right)}
$$

where $k_{2}$ is the rate constant of second model ( $\left.\mathrm{g} / \mathrm{mg} \mathrm{min}\right)$.

Intra-particle diffusion model: It is depended on the Weber and Morris theory; however, the general formula of the diffusion model relates between $\mathrm{qt}$ and $t^{0.5}$ is as follows:

$$
q_{t}=k_{\text {int }} t^{0.5}+\mathrm{C}
$$

where $C$ is the intercept value and gives an idea about the thickness of the boundary layer, and $k_{i n t}$ is the constant for description of adsorption rate in this model $\left(\mathrm{mg} / \mathrm{g} \mathrm{min}^{0.5}\right)$. The intra-particle diffusion occurred if the plot of Equation (5) takes the linear form; however, this mechanism will be the rate-limiting process when the intercept of the linear plot is equal to zero. Otherwise, additional mechanisms may have occurred with process of intra-particle diffusion.

Frequently, it is recognized that the linear relation of diffusion model can be composed of (i) sharper plot in the first region which reflects instantaneous (or external surface) sorption, (ii) gradually varied plot in the second region and this means that the rate limiting may be the intra-particle diffusion, (iii) the equilibrium plot is in the third region and appeared for cases when this diffusion initiates to slow down because of the extreme decrease in the contaminant concentration within the aqueous solution [25].

\subsection{Adsorption Isotherm Models}

Adsorption model is related between the mass of contaminant per unit mass of sorbent $\left(q_{e}\right)$ and the equilibrium concentration of the contaminant $\left(C_{e}\right)[26,27]$. A survey for the isotherms applied in this work can be introduced below: 
Freundlich model: this is the first known expression for description of sorption data and it has the following formula:

$$
q_{e}=K_{F} C_{e}^{\frac{1}{n}}
$$

where $1 / n(<1)$ is the sorption intensity, and $K_{F}$ is reflected the maximum adsorption capacity of the sorbent $[22,28]$.

Langmuir model (1918): this is valid for adsorption of single-layer; however, this model was derived based on the number of assumptions; specifically, the saturation state of all binding sites with molecules of contaminant is equivalent to the maximum adsorption capacity $\left(q_{\max }\right)$, the energy of adsorption must be constant, and no transmigration of contaminant within the plane of the solid surface. Langmuir suggested the formula [22,29] below:

$$
q_{e}=\frac{q_{\max } b C_{e}}{1+b C_{e}}
$$

where $b$ is the slope of Langmuir relationship and; physically, it means the affinity between the contaminant and the sorbent.

\section{Results}

\subsection{Description of Iron Slag}

The porosity, bulk density, ash content, $\mathrm{pH}$ and Brunauer-Emmett-Teller (BET) surface area of the iron slag has the values of $0.41,2.026 \mathrm{~g} / \mathrm{cm}^{3}, 10 \%, 8$ and $0.2571 \mathrm{~m}^{2} / \mathrm{g}$ respectively. Mineralogical composition of granular iron slag was performed at room temperature using XRD analysis as plotted in Figure 1. This analysis certified that the main components of iron slag are diopside (81.6\%), tridymite $(9.5 \%)$, and silicon oxide quartz (8.9\%). Also, XRF analysis was carried out by X-Ray Fluorescence Spectro-Germany to specify the chemical composition of this slag. The outputs of this analysis showed that there is silicon oxide $\left(\mathrm{SiO}_{2}\right)$, iron oxide $\left(\mathrm{Fe}_{2} \mathrm{O}_{3}\right)$, calcium oxide $(\mathrm{CaO})$, aluminum oxide $\left(\mathrm{Al}_{2} \mathrm{O}_{3}\right)$ and manganese oxide $(\mathrm{MnO})$ with percentages reached to 31.2, 9.95, 13.48, 7.933, and 6.853\%, respectively, in the composition of iron slag.

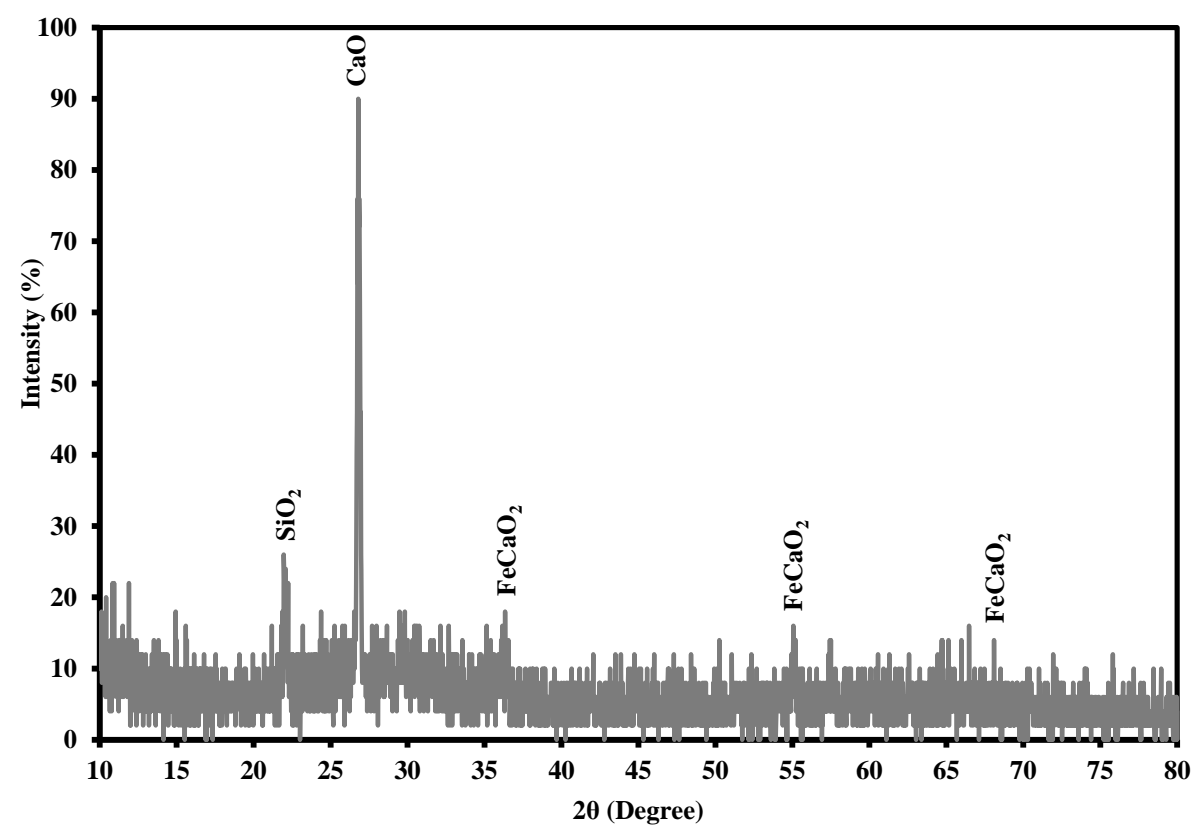

Figure 1. X-ray diffractogram of granular iron slag. 


\subsection{Operational Conditions}

\subsubsection{Equilibrium Time and Initial $\mathrm{pH}$ of the Solution}

The behavior of removal efficiency of the benzaldehyde under the effect of contact time was studied by adding $0.3 \mathrm{~g}$ of granular iron slag to $100 \mathrm{~mL}$ of contaminated solution at room temperature for initial $\mathrm{pH}$ changes from 3 to 7 and measured values are plotted in Figure 2a. In spite of the difference of the initial $\mathrm{pH}$, all curves show the same trend. At initial time until $180 \mathrm{~min}$, rapid increase in the sorption rate can be observed; thereafter, the rate is gradually slowed and this behavior may be due to decrease of the binding sites. The kinetic data measured for interaction of aqueous solution contaminated with benzaldehyde and iron slag illustrated that the best equilibrium is equal to 180 min with maximum removal efficiency of $85 \%$. However, no change can be recognized in the residual concentration beyond this time and this means that all remaining batch experiments can be conducted with time equal to $180 \mathrm{~min}$.
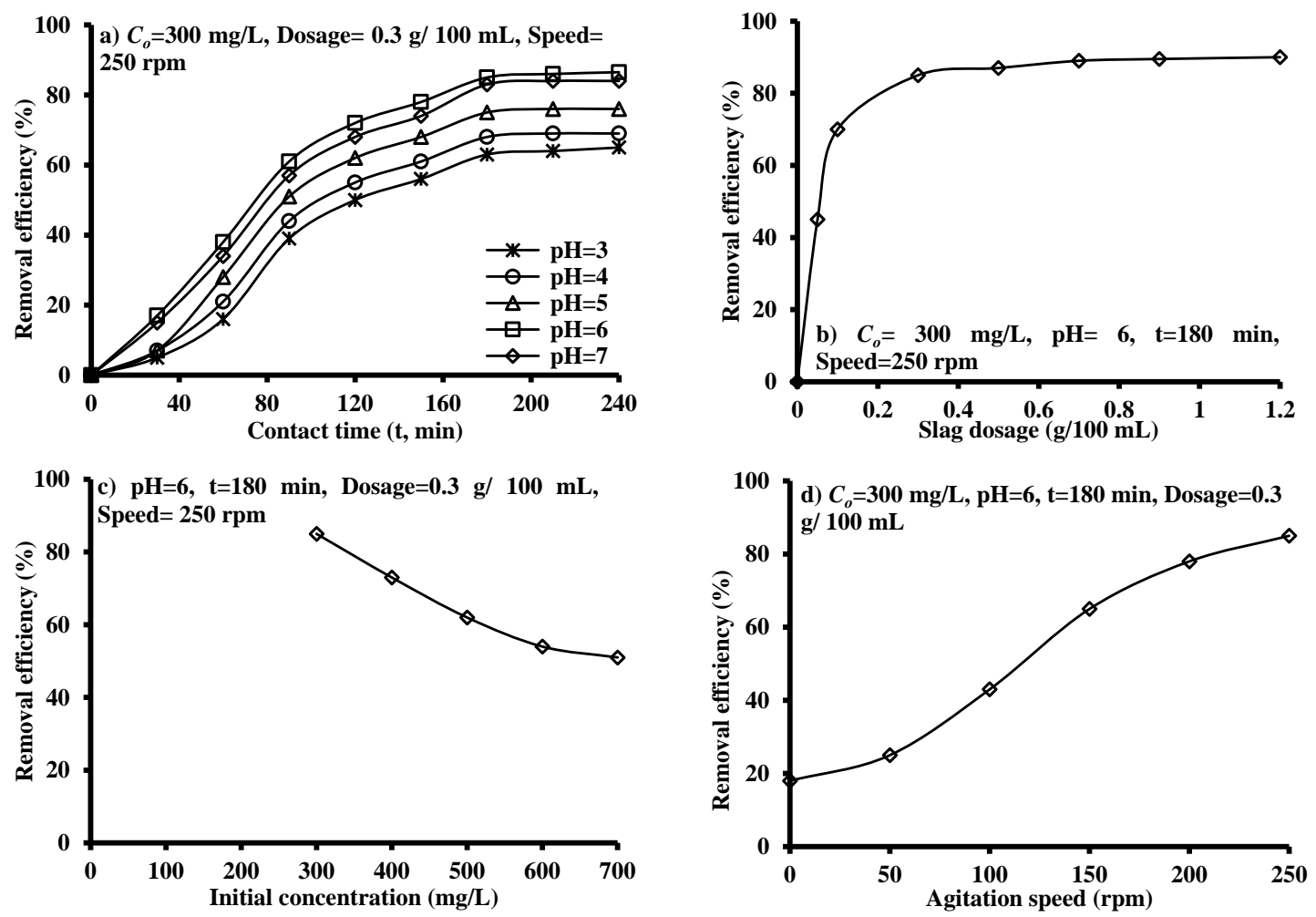

Figure 2. Effect of (a) contact time and initial $\mathrm{pH},(\mathbf{b})$ iron slag dosage, (c) initial concentration and (d) agitation speed on the removal efficiencies of benzaldehyde from contaminated solution.

Also, Figure 2a proved that the removal efficiency is influenced significantly by the values of initial $\mathrm{pH}$ where it increased from $63 \%$ at $\mathrm{pH}$ of 3 to become $85 \%$ at $\mathrm{pH}$ of 6 , and then decreased to $83 \%$ at $\mathrm{pH}$ of 7 at equilibrium time. This trend of variation is applicable for all measurements as a result of initial $\mathrm{pH}$ variation at certain time. The chemical speciation of organic compounds is affected by $\mathrm{pH}$ of water which caused a change in their adsorption properties on granular iron slag. The variations of $\mathrm{pH}$ would affect the zeta potential [30] and forms of functional groups [31,32] responsible for benzaldehyde removal onto the iron slag. The balance between repulsive and attractive forces can be affected by $\mathrm{pH}$ of solution which has significant influence on the adsorption of organic compounds. The protonation-deprotonation transition of these compounds will increase the affinity of adsorption until $\mathrm{pH}$ equal to 6 because this value will enhance the electrostatic adsorption. It is important to know whether there will be any leaching from the iron slag when the slag utilized for treating of water. The two leaching tests are implemented with dosage of $0.3 \mathrm{~g} / 100 \mathrm{~mL}$, speed of $250 \mathrm{rpm}$ and contact 
time of $180 \mathrm{~min}$ for two values of $\mathrm{pH} 3$ and 6 to find the heavy metals concentrations in the leachate. The results of these tests (Table 1) proved that there are no significant concentrations of heavy metals in the resulting leachate.

Table 1. Leachate from iron slag using deionized water.

\begin{tabular}{ccc}
\hline \multirow{2}{*}{ Element } & \multicolumn{2}{c}{ Concentration $(\mathrm{mg} / \mathrm{L})$} \\
\cline { 2 - 3 } & $\mathrm{pH} \mathrm{3}$ & $\mathrm{pH} \mathrm{6}$ \\
\hline $\mathrm{Pb}$ & 0.01 & 0.008 \\
\hline $\mathrm{Cr}$ & n.d. & n.d. \\
\hline $\mathrm{Cu}$ & 0.072 & 0.02 \\
\hline $\mathrm{Zn}$ & n.d. & n.d. \\
\hline n.d.: not detected & & \\
\hline
\end{tabular}

\subsubsection{Slag Dosage and Initial Concentration}

Figure $2 \mathrm{~b}$ reveals that the increase of iron slag dosage will have positive effect on the sorption of benzaldehyde where variation of the dosage from 0.05 to $0.3 \mathrm{~g}$ for $100 \mathrm{~mL}$ of aqueous solution will be associated with increase in uptake efficiency from $45 \%$ to $85 \%$ respectively. This behavior is expected because the higher dosage of sorbent means the higher binding sites; however, the increase of sorbent dosage beyond $0.3 \mathrm{~g} / 100 \mathrm{~mL}$ will not have significant effect on the residual concentration because this concentration reaches a low value. In addition, the relationship between the $C_{o}$ of benzaldehyde and the efficacy of the sorption process was investigated within the range (300-700 $\mathrm{mg} / \mathrm{L}$ ) as plotted in Figure 2c. This plot illustrates that the increase of initial concentration will cause a clear reduction in the sorption efficiency because of the stabilization of the binding sites number [26].

\subsubsection{Agitation Speed}

The sorption efficiency of benzaldehyde onto iron slag due to variation of shaking speed was investigated within the range from zero to $250 \mathrm{rpm}$ with $C_{o}=300 \mathrm{mg} / \mathrm{L}, \mathrm{pH}=6, t=180 \mathrm{~min}$, dosage $=$ $0.3 \mathrm{~g} / 100 \mathrm{~mL}$. The relationship is plotted in Figure $2 \mathrm{~d}$ which proves that the removal increased from $18 \%$ to $85 \%$ when the speed changed from zero to $250 \mathrm{rpm}$ respectively. This is logical behavior for a relation between removal efficiency and agitation speed because the agitation will achieve proper contact between the contaminant in the liquid phase and solid particles; therefore, this will increase the contaminant diffusion towards the surface of these particles.

\subsection{Models of Kinetic Studies}

Kinetic studies were employed to identify the mechanism and sorption rate for removal of benzaldehyde from aqueous solution onto iron slag. These experiments were carried out at sorbent dosage of $0.3 \mathrm{~g} / 100 \mathrm{~mL}$, initial $\mathrm{pH}$ of 6 , and agitation speed of $250 \mathrm{rpm}$ for initial concentrations of 300, 400, 500 and $600 \mathrm{mg} / \mathrm{L}$ and contact time not exceeding $180 \mathrm{~min}$. Pseudo-first and -second order models are fitted with these data (Figure $3 a, b$ ) to interpret the mechanisms responsible for the sorption process [33,34]. When the pseudo-first-order is applicable to the kinetic data, this means that there is linear variation for the rate constant with contaminant concentration [35,36]. However, the pore diffusion will govern the adsorption process in the case where the relationship is non-linear [37]. Origin 2018 software was applied to find the constants of the applied models (Table 2) for system of benzaldehyde and iron slag using non-linear regression analysis. Figure $3 \mathrm{a}, \mathrm{b}$ with Table 2 signified that the interaction of benzaldehyde and iron slag can be well described by the pseudo-first order model because the adsorption capacity approaches from the capacity specified by the equilibrium sorption. Hence, the physical forces are predominant in the sorption of benzaldehyde onto iron slag; also, there is obvious concurrence between the predicted and experimental values. 

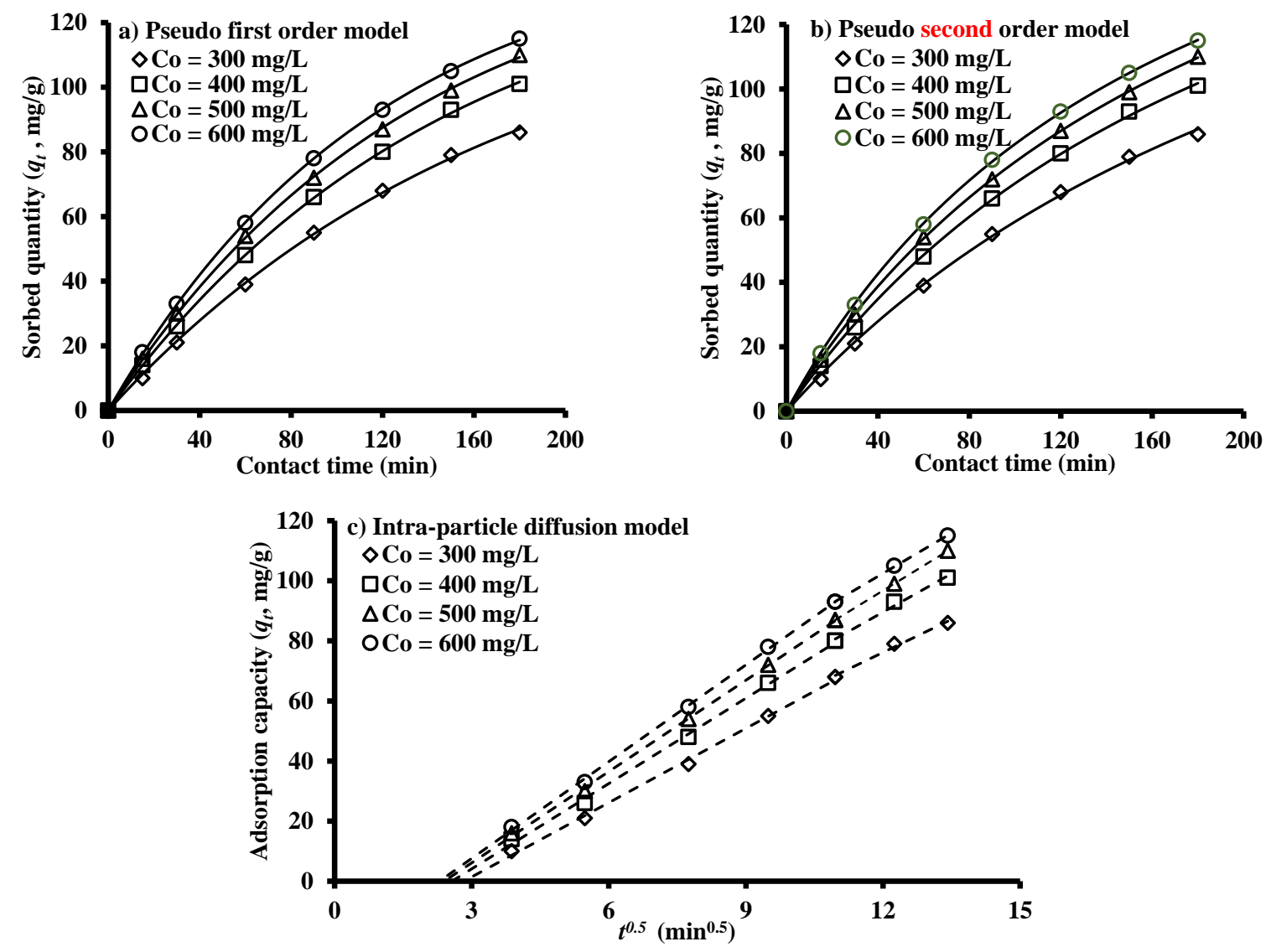

Figure 3. Kinetic models for sorption of benzaldehyde onto iron slag sorbent.

Table 2. Kinetic parameters for the adsorption of benzaldehyde onto iron slag.

\begin{tabular}{|c|c|c|c|c|c|}
\hline \multirow{2}{*}{ Kinetic Model } & \multirow{2}{*}{ Parameter } & \multicolumn{4}{|c|}{$C_{o}(\mathrm{mg} / \mathrm{L})$} \\
\hline & & 300 & 400 & 500 & 600 \\
\hline \multirow{3}{*}{ Pseudo First-Order } & $k_{1}\left(\min ^{-1}\right)$ & 0.0058 & 0.0067 & 0.0075 & 0.0084 \\
\hline & $q_{e}(\mathrm{mg} / \mathrm{g})$ & 134.5 & 144.6 & 147.6 & 147.0 \\
\hline & $R^{2}$ & 0.999 & 0.999 & 0.999 & 0.999 \\
\hline \multirow{4}{*}{ Pseudo Second-Order } & $k_{2}(\mathrm{~g} / \mathrm{mg} \min )$ & 0.000016 & 0.00002 & 0.000022 & 0.000026 \\
\hline & $q_{e}(\mathrm{mg} / \mathrm{g})$ & 225.0 & 225.9 & 230.3 & 224.5 \\
\hline & $h(\mathrm{mg} / \mathrm{g} \min )$ & 0.796 & 1.029 & 1.165 & 1.314 \\
\hline & $R^{2}$ & 0.999 & 0.999 & 0.999 & 0.999 \\
\hline \multirow{6}{*}{ Intra-Particle Diffusion } & \multicolumn{5}{|c|}{ First Portion } \\
\hline & $k_{\text {int }}\left(\mathrm{mg} / \mathrm{g} \min ^{0.5}\right)$ & 8.243 & 9.466 & 10.131 & 10.74 \\
\hline & $R^{2}$ & 0.997 & 0.998 & 0.999 & 0.999 \\
\hline & \multicolumn{5}{|c|}{ Second Portion } \\
\hline & $k_{\text {int }}\left(\mathrm{mg} / \mathrm{g} \min ^{0.5}\right)$ & 7.332 & 8.557 & 9.341 & 8.942 \\
\hline & $R^{2}$ & 0.990 & 0.989 & 1.00 & 0.999 \\
\hline
\end{tabular}

To specify the role of film diffusion and intra-particle diffusion in the removal of benzaldehyde onto iron slag, the model of intra-particle diffusion plots is shown in Figure 3c. This graph shows that the plot is consisted of two regions and intercept with $y$-axis cannot be equal to zero. Consequently, the rate limiting step must not govern by intra-particle diffusion only and there is more than one 
way to describe the sorption mechanism. In the initial stages of removal process, the external mass transfer was predominant [38]; however, the presence of intra-particle diffusion results in the gradual decrease of adsorption in the second linear portion [39]. In addition, there are sufficient vacant sites at the beginning of the sorption process to increase the removal rate and this can be recognized through higher values of slopes for 1st portion (Table 2). Conversely, the lowest slopes (Table 2) for the 2nd portion means that the removal rate or diffusion of contaminant into the micro-pores is slow and this may be due to decrease of the concentration gradient.

\subsection{Sorption Isotherms}

The Origin 2018 software was utilized for calculating the constants of Freundlich and Langmuir models through fitting them with sorption measurements as plotted in Figure 4 using non-linear regression analysis. Outputs of the fitting process (i.e., constants of isotherms and determination coefficients $\left(R^{2}\right)$ ) are inserted in Table 3; however, the two models used are able to describe the interaction of benzaldehyde and iron slag well with $R^{2}>0.86$. Based on Langmuir model, the maximum sorbed quantity of benzaldehyde per unit mass of iron slag was reached to $118.25 \mathrm{mg} / \mathrm{g}$.

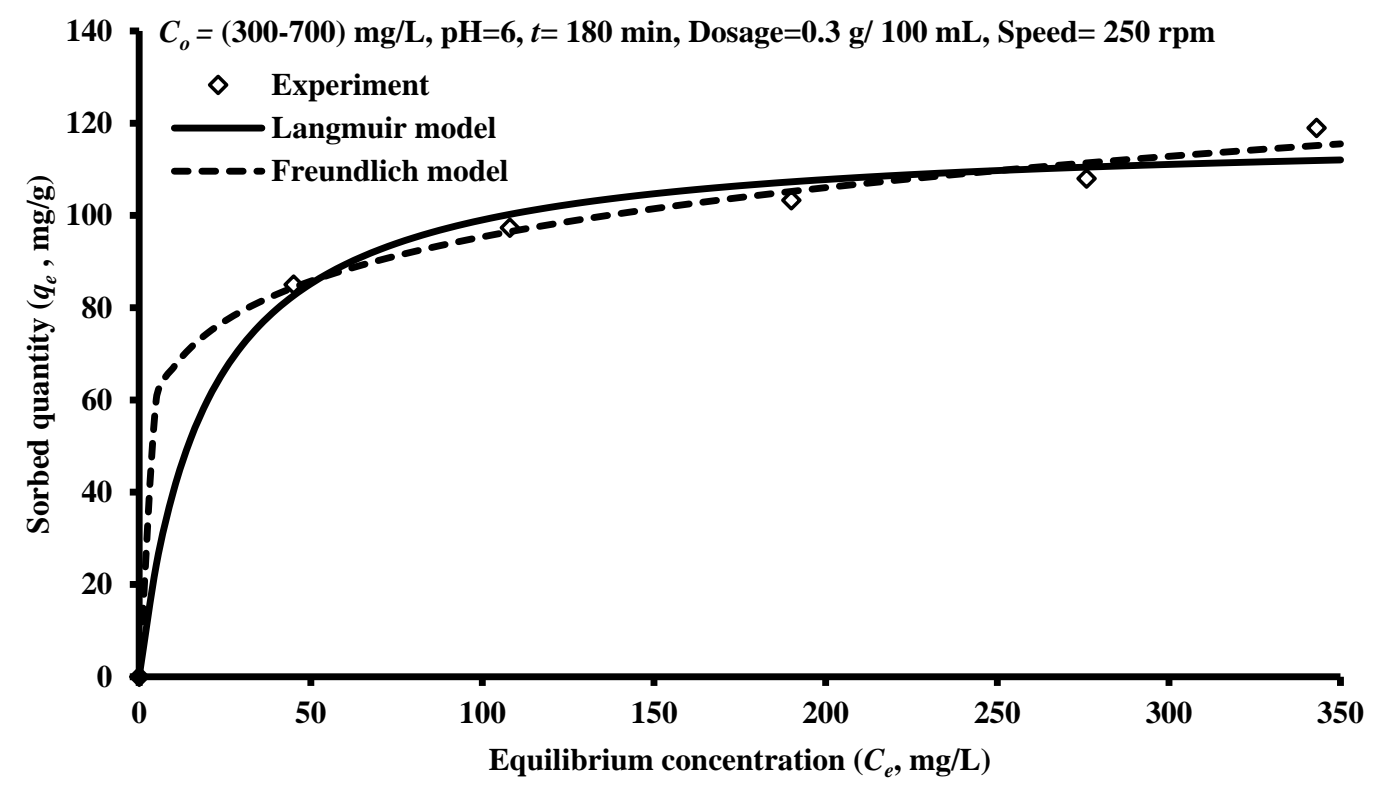

Figure 4. Comparison of the experimental results with the $q_{e}$ values predicted by Freundlich and Langmuir isotherm models for benzaldehyde removal by iron slag.

Table 3. Constants of isotherm models with statistical measure for sorption of benzaldehyde onto iron slag.

\begin{tabular}{ccc}
\hline Isotherm Model & Parameter & Value \\
\hline \multirow{3}{*}{ Freundlich } & $K_{F}(\mathrm{mg} / \mathrm{g})(\mathrm{L} / \mathrm{mg})^{1 / n}$ & 47.12 \\
\cline { 2 - 3 } & $1 / n$ & 0.153 \\
\cline { 2 - 3 } & $R^{2}$ & 0.952 \\
\hline \multirow{2}{*}{ Langmuir } & $b(\mathrm{~L} / \mathrm{mg})$ & 0.052 \\
\cline { 2 - 3 } & $q_{\max }(\mathrm{mg} / \mathrm{g})$ & 118.25 \\
\cline { 2 - 3 } & $R^{2}$ & 0.865 \\
\hline
\end{tabular}




\subsection{Thermodynamics of Adsorption Process}

For the sorption process under consideration, the parameters of thermodynamic (specifically Gibbs free energy change $\left(\Delta G^{\circ}\right)$, entropy change $\left(\Delta S^{\circ}\right)$, and enthalpy change $\left.\left(\Delta H^{\circ}\right)\right)$ have been calculated based on the variation of Langmuir constant $(b)$ with temperature by applying the following relationships:

$$
\begin{gathered}
\Delta G^{\circ}=R T \ln (b) \\
\Delta G^{\circ}=\Delta H^{\circ}-T \Delta S^{\circ} \\
\ln \left(k_{c}\right)=\frac{\Delta S^{\circ}}{R}-\frac{\Delta H^{\circ}}{R T}
\end{gathered}
$$

where $T$ is the absolute temperature $(\mathrm{K}),\left(k_{c}, \mathrm{~L} / \mathrm{g}\right)$ is the coefficient of thermodynamic distribution for the adsorption which is calculated by the division of $q_{e}$ into $C_{e}$ and $R$ is the universal gas constant $\left(8.314 \times 10^{-3} \mathrm{~kJ} \mathrm{~mol}^{-1} \mathrm{~K}^{-1}\right)$.

The linear relationship between $\ln k_{c}$ and $1 / T$ can be used to evaluate the enthalpy change for sorption of benzaldehyde into iron slag for adopted range of temperature by applying the least square analysis as shown in Figure 5. For different values of temperature, Table 4 presents the calculated magnitudes of $\Delta G^{\circ}, \Delta H^{\circ}$, and $\Delta S^{\circ}$ for benzaldehyde adsorption onto iron slag. The positive $\Delta H^{\circ}$. suggests an endothermic adsorption process; however, with temperature increase $\Delta S^{\circ}$. becomes more negative. This reveals that the sorption process is spontaneous and may be enhanced with higher temperature. Moreover, the $\Delta S^{\circ}$ with positive value reveals that there is random increase in the sorbed contaminant at the solid/liquid interface with high affinity.

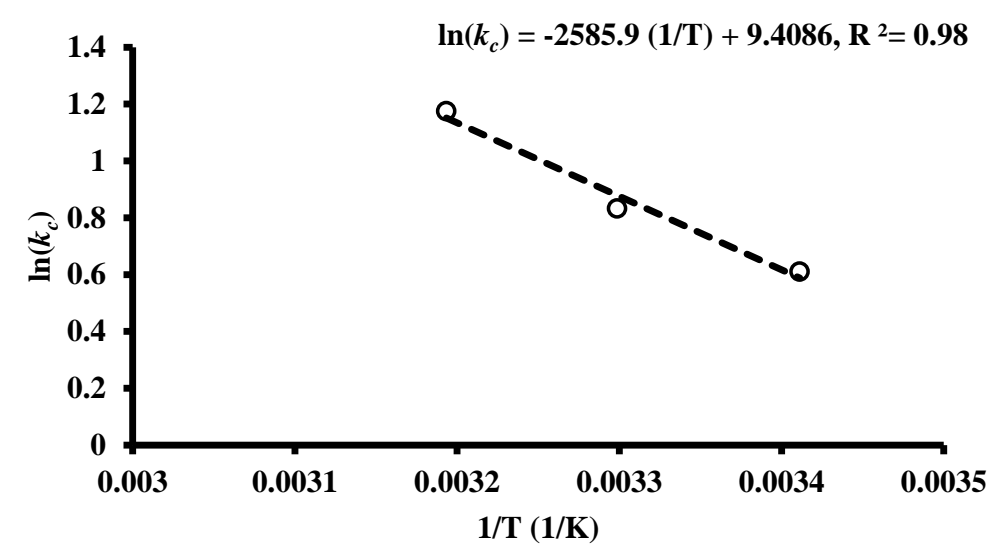

Figure 5. Liner plot related between $\ln \left(k_{c}\right)$ and $1 / T$ for adsorption of benzaldehyde onto iron slag.

Table 4. Values of thermodynamic parameters for adsorption of benzaldehyde onto iron slag.

\begin{tabular}{cccc}
\hline \multirow{2}{*}{ Thermodynamic Parameters } & \multicolumn{3}{c}{ Temperature (K) } \\
\cline { 2 - 4 } & $\mathbf{2 9 3 . 1 5}$ & $\mathbf{3 0 3 . 1 5}$ & $\mathbf{3 1 3 . 1 5}$ \\
\hline$k_{c}$ & 1.84058 & 2.29825 & 3.2381 \\
\hline$\Delta G^{\circ}\left({ }^{*} 10^{3} \mathrm{cal} \mathrm{mol}^{-1}\right)$ & -0.3554 & -0.5013 & -0.7311 \\
\hline$\Delta H^{\circ}\left({ }^{*} 10^{3} \mathrm{cal} \mathrm{mol}^{-1}\right)$ & & 5.81494 \\
\hline$\Delta S^{\circ}\left(\mathrm{cal} \mathrm{mol}^{-1} \mathrm{~K}^{-1}\right)$ & & 18.69577 \\
\hline
\end{tabular}

\section{Predominant Mechanisms}

The most important property of the adsorbent is the surface morphology and the difference in the porosity and structure of this surface can be considered the base for generation of the adsorption capacity. SEM/EDS tests were conducted to investigate the shape and surface morphology of iron slag 
before and after adsorption of benzaldehyde and results are shown in Figure 6. This figure confirms that the surfaces are irregular and this will enhance the adsorption capacity; however, the higher surface area may have resulted from the dissolution of calcium oxide. These results are proved through measurement of the final $\mathrm{pH}$ and concentration of calcium after adsorption process in comparison with those values in the control flask (i.e., sorbent plus deionized water) as illustrated in Table 5. This table reveals the increase of calcium concentration when the initial $\mathrm{pH}$ changed from 3.17 to 6.25; however, this concentration was decreased in the basic range of $\mathrm{pH}$. Based on the output of EDS analysis in Figure 6, significant change in the chemical composition of the iron slag can be observed due to the formation of bridge cations in the presence of large calcium concentration and this may be the cause of the difference in final $\mathrm{pH}$ between and after adsorption and control tests.

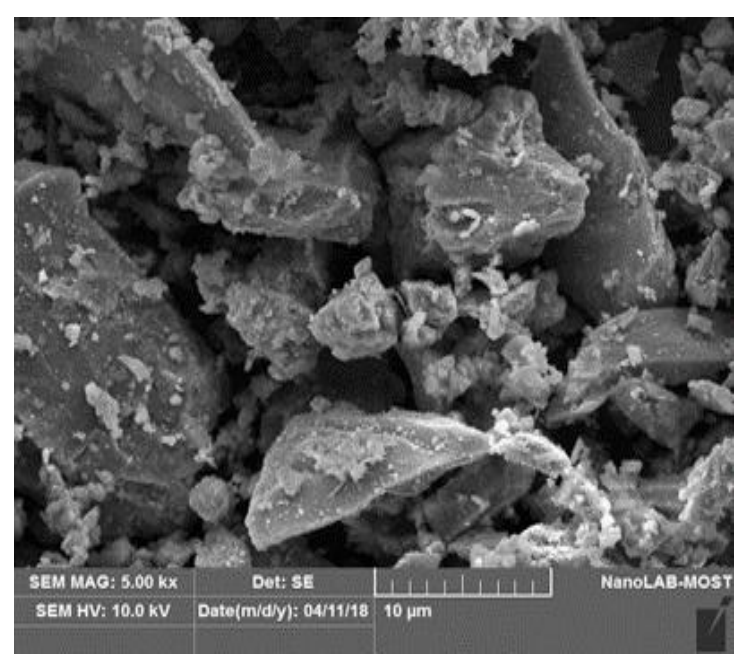

(a)

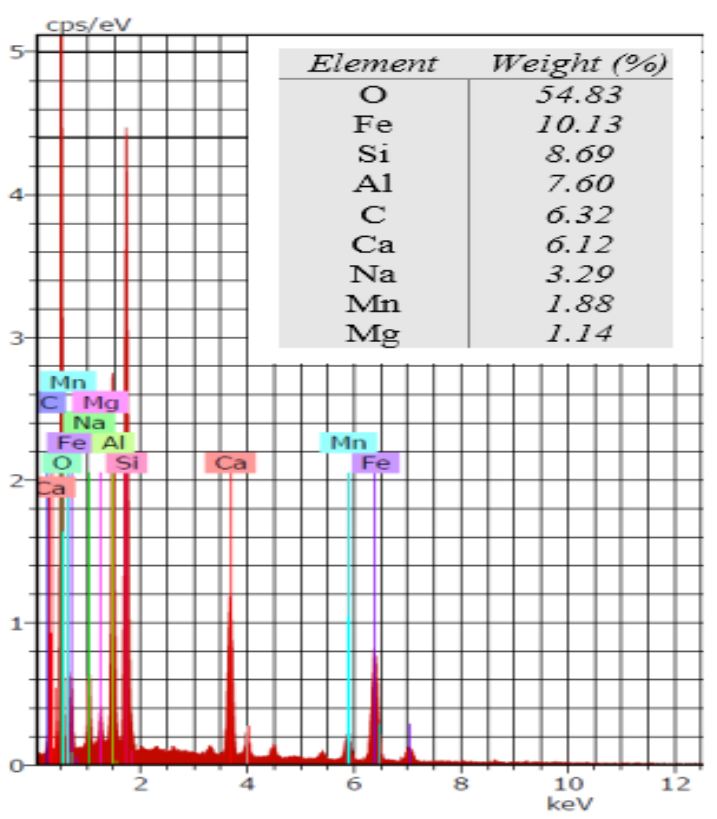

(c)

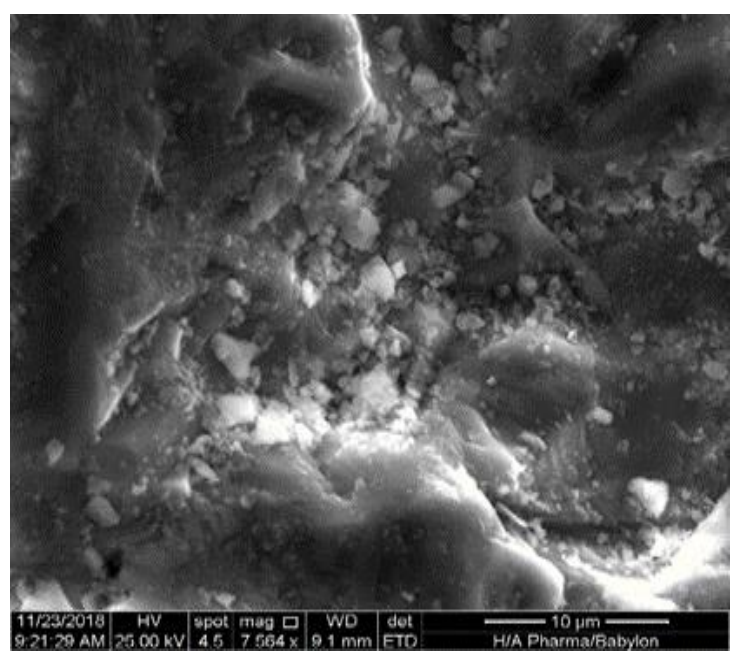

(b)

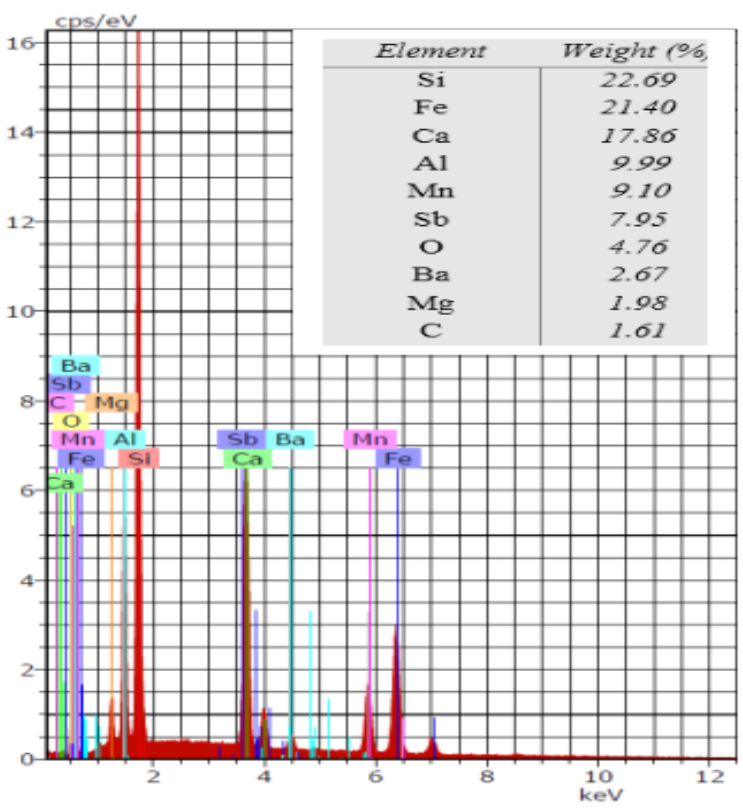

(d)

Figure 6. Scanning electron microscopy/energy-dispersive spectroscopy (SEM/EDS) for iron slag (a), (c) before and (b), (d) after adsorption of benzaldehyde from aqueous solutions. 
Table 5. The values of final $\mathrm{pH}$ and residual concentration of calcium after the sorption of benzaldehyde onto iron slag in comparison with the control test.

\begin{tabular}{ccccc}
\hline \multirow{2}{*}{ Initial $\mathbf{~ p H}$} & \multicolumn{2}{c}{ Control Test } & \multicolumn{2}{c}{ After Adsorption } \\
\cline { 2 - 5 } & Final $\mathbf{~} \mathbf{H}$ & $\mathbf{C a}^{+2}(\mathbf{m g} / \mathbf{L})$ & Final $\mathbf{~ H H}$ & $\mathbf{C a}^{+2}(\mathbf{m g} / \mathbf{L})$ \\
\hline 3.17 & 4.39 & 3.4 & 3.76 & 1.3 \\
\hline 5.9 & 6.49 & 3.2 & 6.3 & 2 \\
\hline 6.25 & 8.20 & 10 & 6.75 & 4 \\
\hline 6.98 & 8.5 & 7 & 7.24 & 5 \\
\hline 8.87 & 6.5 & 2.6 & 7.4 & 0.5 \\
\hline 11 & 10.7 & 0.5 & 10.6 & 0.54 \\
\hline
\end{tabular}

The infrared spectrum of slag before and after adsorption is plotted in Figure 7 and it is clear that the absorption bands of $\mathrm{Si}-\mathrm{O}, \mathrm{Al}-\mathrm{O}, \mathrm{Mg}-\mathrm{O}, \mathrm{Fe}-\mathrm{O}$ and $\mathrm{Ca}-\mathrm{O}$ vibrations appear at wavelengths of 3622 , $1635,1421,996,872,727,530$, and $450 \mathrm{~cm}^{-1}$ (Table 6) [40]. Stretching bands near 1421 and $872 \mathrm{~cm}^{-1}$ represent the existence of calcium with carbonates species and this related with the presence of calcite; however, this is consistent with XRF results. At a wavelength of $3622 \mathrm{~cm}^{-1}$, the surface hydroxyl groups ( $\mathrm{Si}-\mathrm{Si}-\mathrm{OH}$, or $\mathrm{Al}-\mathrm{Al}-\mathrm{OH}$ coupled by $\mathrm{A} 1 \mathrm{MgOH}$ ) can be recognized, while the bending of sorbed water between the layers can be generated at $1635 \mathrm{~cm}^{-1}$. Vibrations of $\mathrm{SiO}_{4}$ could correspond with bands at 996,530 and $450 \mathrm{~cm}^{-1}$. Maximum absorption of silicate minerals was observed at $996 \mathrm{~cm}^{-1}$ while bands at 450 and $530 \mathrm{~cm}^{-1}$ could be $\mathrm{Si}-\mathrm{O}-\mathrm{Si}$ and $\mathrm{Al}-\mathrm{O}-\mathrm{Si}$ bending vibrations, respectively. The structure of the molecules under consideration consists of the benzene ring to which the $\mathrm{C}=\mathrm{O}$ group and the hydrogen atom are bonded; in addition, various substituents can be bonded to different positions of the ring. As a rule, to identify compounds that contain the aldehyde-CHO group, their infrared (IR) spectra are studied in detail in the range $1760-1640 \mathrm{~cm}^{-1}$, in which strong absorption bands of $\mathrm{C}=\mathrm{O}$ vibrations are observed, and in the range $2900-2700 \mathrm{~cm}^{-1}$, where characteristic absorption bands of stretching vibrations of the aldehyde $\mathrm{C}-\mathrm{H}$ group are located [41-43]. Figure 7 signifies that the spectrum of aqueous solution with benzaldehyde includes a very strong band at $1623 \mathrm{~cm}^{-1}$ identical to the $\mathrm{C}=\mathrm{O}$ bond [43]. For adsorbed benzaldehyde, this band is also available in the spectra and this suggests that it belongs to a weakly adsorbed/physisorbed species. During the adsorption of benzaldehyde, new shoulder observes at $1625 \mathrm{~cm}^{-1}$ due to vibration of a weakened $\mathrm{C}=\mathrm{O}$ bond in a covalent carboxylate-type structure [44,45]. For aqueous solution with benzaldehyde after adsorption, the disappearance of a band at $1383 \mathrm{~cm}^{-1}$ is supported by the breakage of the aldehydic $\mathrm{C}-\mathrm{H}$ bond. This band has been previously assigned to a bending vibration of the aldehydic $\mathrm{C}-\mathrm{H}$ bond $[46,47]$. Through the sorption of substituted benzaldehyde onto iron oxides, Kung and McBride [48] proved that there are two bands in this region and they identified them as the symmetric stretching vibration of different benzoate species. The authors proposed that these bands may or may not be resolved based on the substituent groups present and they identical to the two benzoate species at wavelengths of 1560 and $1495 \mathrm{~cm}^{-1}$. Also, Vanhengstum [44] identified two bands for surface benzoate species coordinated to a single surface metal ion at 1500 and $1410 \mathrm{~cm}^{-1}$. At $1493 \mathrm{~cm}^{-1}$, a weak band may be assigned to the asymmetric stretching vibration of the same species. 


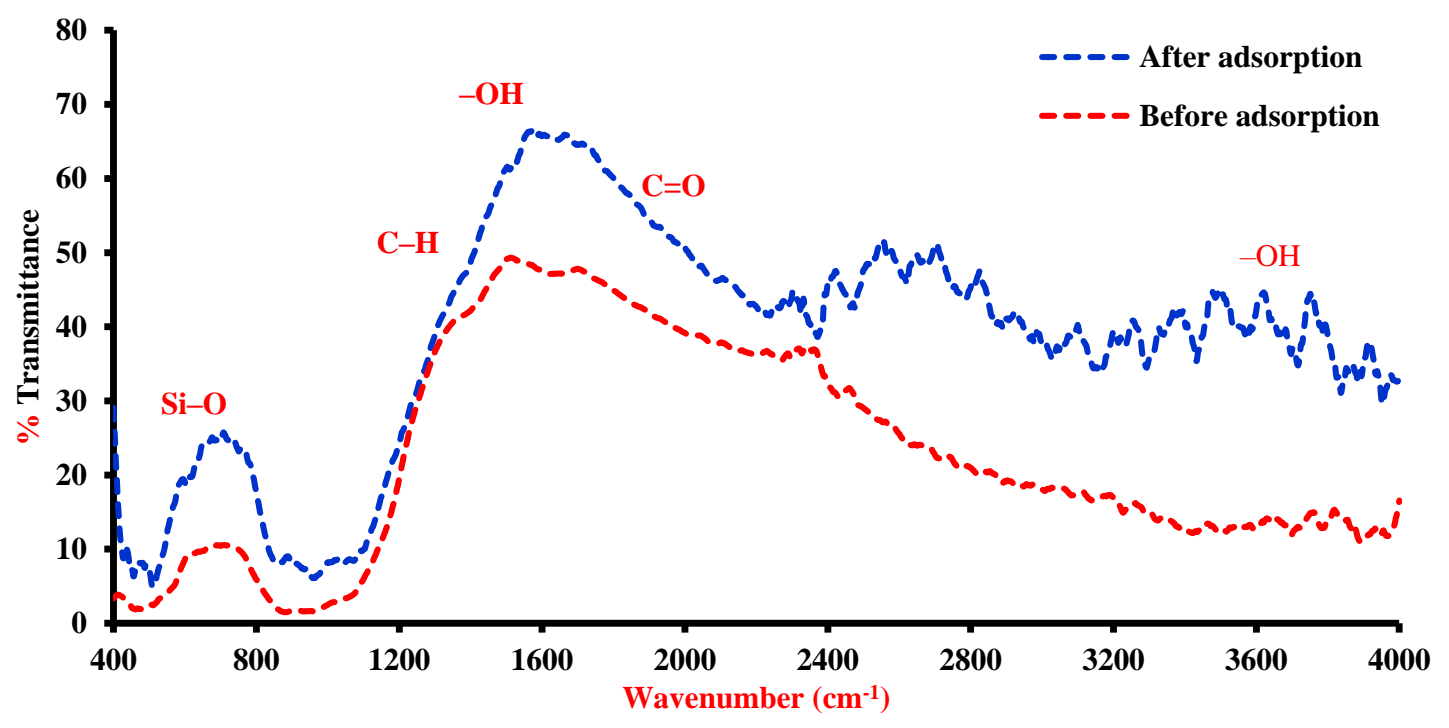

Figure 7. Fourier transform infrared (FT-IR) spectra for iron slag before and after adsorption process.

Table 6. Functional groups responsible of benzaldehyde onto iron slag.

\begin{tabular}{cc}
\hline Band $\left(\mathbf{c m}^{-\mathbf{1}}\right)$ & Functional Group \\
\hline 996,530 and 450 & $\mathrm{Si}-\mathrm{O}$ \\
\hline 450 & $\mathrm{Ca}-\mathrm{O}$ \\
\hline 1421 and 872 & $\mathrm{C}-\mathrm{O}$ \\
\hline 3622 & $\mathrm{Si}-\mathrm{Si}-\mathrm{OH}$ or $\mathrm{Al}-\mathrm{Al}-\mathrm{OH}$ \\
\hline 1635 & $\mathrm{~A} 1 \mathrm{MgOH}$ \\
\hline
\end{tabular}

However, the properties in this range (Ca $1470-1530 \mathrm{~cm}^{-1}$ ) cannot be distinguished easily because of the strong IR beam absorbance by the sample. Bands at 1160, 1175, 1306, 1447, and $1601 \mathrm{~cm}^{-1}$ are shifted slightly after adsorption in comparison with their original positions. This may result from the vibrations of pure aromatic ring as well as to mixed modes of $\mathrm{CH}$ in plane bending and vibrations of $\mathrm{C}=\mathrm{C}$ stretching $[44,49,50]$. This means that this ring stays intact through the interaction of slag sorbent and benzaldehyde.

\section{Conclusions}

Due to the use of solid waste (i.e., iron slag) in the reclamation of wastewater, the present study is considered a real application for the sustainability principles. The outputs of batch studies confirmed that this material is more effective and dependable for removing of benzaldehyde present in water with removal efficiency and maximum adsorption capacity reached to $85 \%$ and $118.25 \mathrm{mg} / \mathrm{g}$ respectively. These values are achieved at best operational conditions of; slag mass of $0.3 \mathrm{~g}$ added to $100 \mathrm{~mL}$ of contaminated water, initial $\mathrm{pH}$ of 6, time of $180 \mathrm{~min}$, shaking speed of $250 \mathrm{rpm}$ for initial concentration of $300 \mathrm{mg} / \mathrm{L}$. The isotherm models in conjugation with kinetic studies elucidated that the physical sorption has a major role in the removal process. However, thermodynamic analysis certified that the sorption process is spontaneous and endothermic. All characterization tests (i.e., SEM, EDS, and FT-IR) elucidated that there is a significant dissolution in the calcium oxide (which formed $13.48 \%$ of natural slag) and this will increase the surface area. The increase of dissolved calcium concentration may be responsible for bridge cation formation to eliminate the contaminant for aqueous solution. Also, the outputs of FT-IR analysis signified that the aromatic ring stays intact through the interaction of iron slag and benzaldehyde. 
Author Contributions: This paper reflects a result of collective teamwork. A.A.H.F., S.S.A. and L.A.N. designed the experiments and wrote the manuscript. M.N. helped in the final editing of the manuscript. All authors contributed equally to this study. All authors have read and agreed to the published version of the manuscript.

Funding: One of the authors (Mu. Naushad) is grateful to the Researchers Supporting Project number (RSP-2019/8), King Saud University, Riyadh, Saudi Arabia, for the support.

Acknowledgments: We would like to gratefully acknowledge the technical support of the Environmental Engineering Department/University of Baghdad provided during the present work. One of the authors (Mu. Naushad) is grateful to the Researchers Supporting Project number (RSP-2019/8), King Saud University, Riyadh, Saudi Arabia for the support.

Conflicts of Interest: The authors declare no conflict of interest.

\section{References}

1. Rajoriya, R.K.; Prasad, B.; Mishra, I.M.; Wasewar, K.L. Adsorption of benzaldehyde on granular activated carbon: Kinetics, equilibrium, and thermodynamic. Chem. Biochem. Eng. Q. 2007, 3, 219-226.

2. Opgrande, J.L.; Dobratz, C.J.; Brown, E.; Liang, J.; Conn, G.S.; Shelton, F.J.; With, J. Benzaldehyde. In Kirk-Othmer Encyclopedia of Chemical Technology; John Wiley \& Sons, Inc.: Hoboken, NJ, USA, 2000.

3. Shahbeig, H.; Bagheri, N.; Ghorbanian, S.A.; Hallajisani, A.; Poorkarimi, S. A new adsorption isotherm model of aqueous solutions on granular activated carbon. World J. Model. Simul. 2013, 9, 243-254.

4. Saritha, P.; Aparna, C.; Himabindu, V.; Anjaneyulu, Y. Comparison of various advanced oxidation processes for the degradation of 4-chloro-2 nitrophenol. J. Hazard. Mater. 2007, 149, 609-614. [CrossRef] [PubMed]

5. Murthy, H.M.R.; Manonmani, H.K. Aerobic degradation of technical hexachlorocyclohexane by a defined microbial consortium. J. Hazard. Mater. 2007, 149, 18-25. [CrossRef] [PubMed]

6. Ahmad, A.L.; Tan, L.S.; Shukor, S.R.A. Dimethoate and atrazine retention from aqueous solution by nanofiltration membranes. J. Hazard. Mater. 2008, 151, 71-77. [CrossRef] [PubMed]

7. Maldonado, M.; Malato, S.; Perezestrada, L.; Gernjak, W.; Oller, I.; Domenech, X.; Peral, J. Partial degradation of five pesticides and an industrial pollutant by ozonation in a pilot-plant scale reactor. J. Hazard. Mater. 2006, 138, 363-369. [CrossRef] [PubMed]

8. Naushad, M.; ALOthman, Z.A. Separation of toxic Pb2+ metal from aqueous solution using strongly acidic cation-exchange resin: Analytical applications for the removal of metal ions from pharmaceutical formulation. Desalin. Water Treat. 2015, 53, 2158-2166. [CrossRef]

9. Mironyuk, I.; Tatarchuk, T.; Naushad, M.; Vasylyeva, H.; Mykytyn, I. Highly efficient adsorption of strontium ions by carbonated mesoporous TiO 2. J. Mol. Liq. 2019, 285, 742-753. [CrossRef]

10. Naushad, M.; Mittal, A.; Rathore, M.; Gupta, V. Ion-exchange kinetic studies for Cd(II), Co(II), Cu(II), and $\mathrm{Pb}$ (II) metal ions over a composite cation exchanger. Desalin. Water Treat. 2015, 54, 2883-2890. [CrossRef]

11. Naushad, M.; Sharma, G.; Kumar, A.; Sharma, S.; Ghfar, A.A.; Bhatnagar, A.; Stadler, F.J.; Khan, M.R. Efficient removal of toxic phosphate anions from aqueous environment using pectin based quaternary amino anion exchanger. Int. J. Biol. Macromol. 2018, 106, 1-10. [CrossRef]

12. Awual, M.R.; Hasan, M.M.; Naushad, M.; Shiwaku, H.; Yaita, T. Preparation of new class composite adsorbent for enhanced palladium(II) detection and recovery. Sensors Actuators B Chem. 2015, 209, 790-797. [CrossRef]

13. Awual, R.; Eldesoky, G.E.; Yaita, T.; Naushad, M.; Shiwaku, H.; Alothman, Z.A.; Suzuki, S. Schiff based ligand containing nano-composite adsorbent for optical copper (II) ions removal from aqueous solutions. Chem. Eng. J. 2015, 279, 639-647. [CrossRef]

14. Meghea, A.; Rehner, H.H.; Peleanu, I.; Mihalache, R. Test-fitting on adsorption isotherms of organic pollutants from waste waters on activated carbon. J. Radioanal. Nucl. Chem. 1998, 229, 105-110. [CrossRef]

15. Tatarchuk, T.; Paliychuk, N.; Bitra, R.B.; Shyichuk, A.; Naushad, M.; Mironyuk, I.; Ziółkowska, D. Adsorptive removal of toxic Methylene Blue and Acid Orange 7 dyes from aqueous medium using cobalt-zinc ferrite nanoadsorbents. Desalin. Water Treat. 2019, 150, 374-385. [CrossRef]

16. Naushad, M.; Sharma, G.; Alothman, Z.A. Photodegradation of toxic dye using Gum Arabic-crosslinked-poly(acrylamide)/ $\mathrm{Ni}(\mathrm{OH}) 2 / \mathrm{FeOOH}$ nanocomposites hydrogel. J. Clean. Prod. 2019, 241, 118263. [CrossRef]

17. Sharma, G.; Naushad, M.; Pathania, D.; Mittal, A.; El-desoky, G.E. Modification of Hibiscus cannabinus fiber by graft copolymerization: Application for dye removal. Desalin. Water Treat. 2015, 54, 3114-3121. [CrossRef] 
18. Duman, O.; Ayranci, E. Adsorption Characteristics of Benzaldehyde, Sulphanilic acid, and p-Phenolsulfonate from Water, Acid, or Base Solutions onto Activated Carbon Cloth. Sep. Sci. Technol. 2006, 41, 3673-3692. [CrossRef]

19. Zaitan, H.; Mohamed, E.F.; Valdés, H.; Nawdali, M.; Rafqah, S.; Manero, M.H. Toluene, Methanol and Benzaldehyde Removal from Gas Streams by Adsorption onto Natural Clay and Faujasite-Y type Zeolite. Acta Chim. Slov. 2016, 63, 798-808. [CrossRef]

20. Proctor, D.M.; Fehling, K.A.; Shay, E.C.; Wittenborn, J.L.; Green, J.J.; Avent, C.; Bigham, R.D.; Connolly, M.; Lee, B.; Shepker, T.O.; et al. Physical and Chemical Characteristics of Blast Furnace, Basic Oxygen Furnace, and Electric Arc Furnace Steel Industry Slags. Environ. Sci. Technol. 2000, 34, 1576-1582. [CrossRef]

21. Tsakiridis, P.E.; Papadimitriou, G.D.; Tsivilis, S.; Koroneos, C. Utilization of steel slag for Portland cement clinker production. J. Hazard. Mater. 2008, 152, 805-811. [CrossRef]

22. Naji, L.A.; Jassam, S.H.; Yaseen, M.J.; Faisal, A.A.H.; Al-Ansari, N. Modification of Langmuir model for simulating initial $\mathrm{pH}$ and temperature effects on sorption process. Sep. Sci. Technol. 2019, 1-8. [CrossRef]

23. Weber, W.; Morris, J. Advances in Water Pollution Research: Removal of Biologically Resistant Pollutant from Waste Water by adsorption. In Proceedings of the International Conference on Water Pollution Symposium; Pergamon Press: Oxford, UK, 1962; pp. 231-266.

24. Ho, Y.S.; McKay, G. Pseudo-second order model for sorption processes. Process Biochem. 1999, 34, 451-465. [CrossRef]

25. Wu, F.C.; Tseng, R.L.; Juang, R.S. Comparisons of porous and adsorption properties of carbons activated by steam and KOH. J. Colloid Interface Sci. 2005, 283, 49-56. [CrossRef] [PubMed]

26. Faisal, A.A.H.; Naji, L.A. Simulation of Ammonia Nitrogen Removal from Simulated Wastewater by Sorption onto Waste Foundry Sand Using Artificial Neural Network. Assoc. Arab Univ. J. Eng. Sci. 2019, 26, 28-34. [CrossRef]

27. Saad, N.; Abd Ali, Z.T.; Naji, L.A.; AAH Faisal, A. Development of Bi-Langmuir model for description initial $\mathrm{pH}$ and temperature effects on the sorption of cadmium onto waste foundry sand. Environ. Eng. Res. 2019. [CrossRef]

28. Gheju, M.; Miulescu, A. Sorption Equilibrium of Hexavalent Chromium on Granular Activated Carbon. Chem. Bull. POLITEHNICA Univ. 2007, 52, 1-2.

29. Foo, K.Y.; Hameed, B.H. Insights into the modeling of adsorption isotherm systems. Chem. Eng. J. 2010, 156, 2-10. [CrossRef]

30. Nguyen, T.C.; Loganathan, P.; Nguyen, T.V.; Kandasamy, J.; Naidu, R.; Vigneswaran, S. Adsorptive removal of five heavy metals from water using blast furnace slag and fly ash. Environ. Sci. Pollut. Res. 2018, 25, 20430-20438. [CrossRef]

31. Berthod, A.; Carda-Broch, S.; Garcia-Alvarez-Coque, M.C. Hydrophobicity of Ionizable Compounds. A Theoretical Study and Measurements of Diuretic Octanol-Water Partition Coefficients by Countercurrent Chromatography. Anal. Chem. 1999, 71, 879-888. [CrossRef]

32. Wu, W.; Jiang, W.; Xia, W.; Yang, K.; Xing, B. Influence of $\mathrm{pH}$ and surface oxygen-containing groups on multiwalled carbon nanotubes on the transformation and adsorption of 1-naphthol. J. Colloid Interface Sci. 2012, 374, 226-231. [CrossRef]

33. Ho, Y. The kinetics of sorption of divalent metal ions onto sphagnum moss peat. Water Res. 2000, 34, 735-742. [CrossRef]

34. Drweesh, S.A.; Fathy, N.A.; Wahba, M.A.; Hanna, A.A.; Akarish, A.I.M.; Elzahany, E.A.M.; El-Sherif, I.Y.; Abou-El-Sherbini, K.S. Equilibrium, kinetic and thermodynamic studies of $\mathrm{Pb}$ (II) adsorption from aqueous solutions on HCl-treated Egyptian kaolin. J. Environ. Chem. Eng. 2016, 4, 1674-1684. [CrossRef]

35. Kalhori, E.M.; Al-Musawi, T.J.; Ghahramani, E.; Kazemian, H.; Zarrabi, M. Enhancement of the adsorption capacity of the light-weight expanded clay aggregate surface for the metronidazole antibiotic by coating with $\mathrm{MgO}$ nanoparticles: Studies on the kinetic, isotherm, and effects of environmental parameters. Chemosphere 2017, 175, 8-20. [CrossRef] [PubMed]

36. Nashine, A.L.; Tembhurkar, A.R. Equilibrium, kinetic and thermodynamic studies for adsorption of As(III) on coconut (Cocos nucifera L.) fiber. J. Environ. Chem. Eng. 2016, 4, 3267-3273. [CrossRef]

37. Konggidinata, M.I.; Chao, B.; Lian, Q.; Subramaniam, R.; Zappi, M.; Gang, D.D. Equilibrium, kinetic and thermodynamic studies for adsorption of BTEX onto Ordered Mesoporous Carbon (OMC). J. Hazard. Mater. 2017, 336, 249-259. [CrossRef] 
38. Bedin, K.C.; Martins, A.C.; Cazetta, A.L.; Pezoti, O.; Almeida, V.C. KOH-activated carbon prepared from sucrose spherical carbon: Adsorption equilibrium, kinetic and thermodynamic studies for Methylene Blue removal. Chem. Eng. J. 2016, 286, 476-484. [CrossRef]

39. Fierro, V.; Torné-Fernández, V.; Montané, D.; Celzard, A. Adsorption of phenol onto activated carbons having different textural and surface properties. Microporous Mesoporous Mater. 2008, 111, 276-284. [CrossRef]

40. Rahman, A.; Kumar, S.; Bafana, A.; Dahoumane, S.; Jeffryes, C. Individual and Combined Effects of Extracellular Polymeric Substances and Whole Cell Components of Chlamydomonas reinhardtii on Silver Nanoparticle Synthesis and Stability. Molecules 2019, 24, 956. [CrossRef]

41. Silverstein, R.M.; Bassler, G.C. Spectrometric identification of organic compounds. J. Chem. Educ. 1962, 39, 546. [CrossRef]

42. Hoffman, R.V. Structure Determination of Organic Compounds. In Organic Chemistry; John Wiley \& Sons, Inc.: Hoboken, NJ, USA, 2005; pp. 332-394.

43. Tolstorozhev, G.B.; Skornyakov, I.V.; Bel'kov, M.V.; Shadyro, O.I.; Brinkevich, S.D.; Samovich, S.N. IR spectra of benzaldehyde and its derivatives in different aggregate states. Opt. Spectrosc. 2012, 113, 179-183. [CrossRef]

44. Vanhengstum, A. Infrared study of the selective oxidation of toluene and o-xylene on vanadium oxide/TiO2. J. Catal. 1986, 101, 323-330. [CrossRef]

45. Besselmann, S.; Löffler, E.; Muhler, M. On the role of monomeric vanadyl species in toluene adsorption and oxidation on V2O5/TiO2 catalysts: A Raman and in situ DRIFTS study. J. Mol. Catal. A Chem. 2000, 162, 401-411. [CrossRef]

46. Lampert, H.; Mikenda, W.; Karpfen, A. Molecular Geometries and Vibrational Spectra of Phenol, Benzaldehyde, and Salicylaldehyde: Experimental versus Quantum Chemical Data. J. Phys. Chem. A 1997, 101, 2254-2263. [CrossRef]

47. Palomar, J.; De Paz, J.L.G.; Catalán, J. Vibrational study of intramolecular hydrogen bonding in o-hydroxybenzoyl compounds. Chem. Phys. 1999, 246, 167-208. [CrossRef]

48. Kung, K.-H.; McBride, M.B. Adsorption of Para-substituted Benzoates on Iron Oxides. Soil Sci. Soc. Am. J. 1989, 53, 1673. [CrossRef]

49. Naushad, M. Surfactant assisted nano-composite cation exchanger: Development, characterization and applications for the removal of toxic $\mathrm{Pb} 2+$ from aqueous medium. Chem. Eng. J. 2014, 235, 100-108. [CrossRef]

50. Díez, V. Effect of the chemical composition on the catalytic performance of MgyAlOx catalysts for alcohol elimination reactions. J. Catal. 2003, 215, 220-233. [CrossRef] 